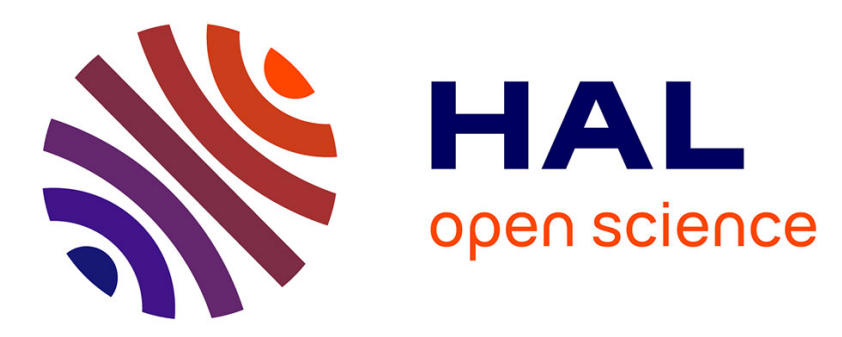

\title{
One-two punches to eliminate depredation by marine mammals on fish caught or raised for human consumption
}

\author{
Andrew W Trites, Jérôme Spitz
}

\section{- To cite this version:}

Andrew W Trites, Jérôme Spitz. One-two punches to eliminate depredation by marine mammals on fish caught or raised for human consumption. Animal Conservation, 2016, 10.1111/acv.12291 . hal-03023760

\author{
HAL Id: hal-03023760 \\ https://hal.science/hal-03023760
}

Submitted on 25 Nov 2020

HAL is a multi-disciplinary open access archive for the deposit and dissemination of scientific research documents, whether they are published or not. The documents may come from teaching and research institutions in France or abroad, or from public or private research centers.
L'archive ouverte pluridisciplinaire HAL, est destinée au dépôt et à la diffusion de documents scientifiques de niveau recherche, publiés ou non, émanant des établissements d'enseignement et de recherche français ou étrangers, des laboratoires publics ou privés. 


\title{
One-two punches to eliminate depredation by marine mammals on fish caught or raised for human consumption
}

\author{
A. W. Trites ${ }^{1} \&$ J. Spitz ${ }^{2}$ \\ 1 Marine Mammal Research Unit, Institute for the Oceans and Fisheries, University of British Columbia, Vancouver, BC, Canada \\ 2 Observatoire PELAGIS, UMS 3462, Université de La Rochelle/CNRS, La Rochelle, France
}

\section{Correspondence}

Andrew W. Trites, Marine Mammal Research Unit, Institute for the Oceans and Fisheries, University of British Columbia, Room 247, AERL, 2202 Main Mall, Vancouver, BC, Canada V6T 1 Z4.

Email: a.trites@oceans.ubc.ca

doi: 10.1111/acv.12291

Clashes have occurred between fisheries and marine mammals ever since people first began catching and raising fish. These human-wildlife conflicts have been exacerbated more recently by the legal protections afforded to marine mammals and by the increased demand by people for wild-caught and farmed fish (Gales, Hindell \& Kirkwood, 2003). Losses caused by marine mammals account for $2-10 \%$ of the landed value of aquatic-farm production (Nash, Iwamoto \& Mahnken, 2000), but solutions to mitigate this problem have been few and far between (Gales et al., 2003; Fertl, 2009; Schakner \& Blumstein, 2013). Shooting individuals and culling populations has never been a long-term solution, and most societies no longer consider these acceptable practices (Gales et al., 2003). However, attempts to employ solutions that are more ethical have been expensive or ineffective (Gales et al., 2003), or have caused greater harm than good such as attracting other predators (the dinner bell effect; Fertl, 2009), or scaring and displacing non-targeted species (e.g. Brandt et al., 2013). Harvesters, therefore, remain poised for a non-lethal technological breakthrough, such as that proposed by Götz \& Janik (2016), to protect their livelihoods and successfully market their fish (e.g. CERMAQ, 2012).

On the surface, Götz and Janik have developed and tested an effective means using only adverse sounds tuned to the hearing and behaviour of phocid seals to deter these predators from killing salmon at three fish farms. They found slightly lower surfacings of harbour seals Phoca vitulina within $100 \mathrm{~m}$ of their loudspeakers when exposed to the sounds, and no effect of the sound exposure on harbour porpoise Phocoena phocoena and European otter Lutra lutra distributions around the sonified farms. Most impressively, they showed that the number of fish lost to seal damage when sounds were emitted was reduced by $91-97 \%$ depending on the site and test conducted.
At first look, it would appear that producing speciesspecific startle responses without inflicting avoidance behaviours from other species may be the long-awaited panacea for the economic losses caused by marine mammals depredating fishing nets and feeding on pen-raised fish. But, could the solution to this conflict really be this simple?

Unfortunately, percentages presented alone, without reference to the absolute numbers they are based on, can be deceptive. Götz \& Janik (2016) did not indicate the absolute numbers, but it would appear the seals killed and partially ate an average of $\sim 30$ fish per week per cage at the short-term test sites, or about four fish per day in the absence of deterrence, and $<3$ fish per week during these sound experiments (see fig. 2 in Götz \& Janik, 2016). In terms of numbers of seals that might have been responsible for the predation, there were only 10 or fewer seal surfacings per hour within $100 \mathrm{~m}$ of the transducer at the control sites (see fig. 4a in Götz \& Janik, 2016). Thus, it is possible that the mortality at the studied fish farms could have been caused by a limited number of seals, maybe just a single animal given that an adult requires $\sim 3 \mathrm{~kg}$ of fish per day (e.g. Howard et al., 2013) and surfaces $\sim 12-20$ times per hour (based on mean dive times of 3-5 min; e.g. Wilson et al., 2014).

In terms of finding no effect of the adverse sounds on harbour porpoise, the median number of harbour porpoise surfacings per hour observed was 0 during the control period, and slightly above 0 when exposed to sound (see fig. 4c in Götz \& Janik, 2016). This lack of longterm effect of sound on the presence of other species may, therefore, simply reflect harbour porpoise being a rare species near their study sites, or (in the absence of knowing samples sizes) that there was no statistical power to detect an effect of the sound on porpoise behaviour had there actually been one. 
It is, however, noteworthy that a previous 2-month test of this seal-scaring device found sound exposure caused seal numbers to drop sharply within $250 \mathrm{~m}$ of the device, but had no short-term effect on porpoise numbers (Götz \& Janik, 2015). It is equally noteworthy that 1 or 2 seals in this study tolerated the sound within $250 \mathrm{~m}$, and that two grey seals Halichoerus grypus in earlier captive trials could not be startled (Götz \& Janik, 2011). These studies imply that sounds can indeed alarm one species, and not another, but they also show that the alarming sounds may not deter some targeted individuals.

The point of our criticisms is not to lessen the importance of what Götz and Janik have done (because we think they are onto something that is very promising), but to wave a cautionary flag in front of those who may rush to announce the findings and apply this new technology to other systems and geographic locations without sufficient reflection (e.g. Tyndall \& Cosgrove, 2016). History has shown a number of new deterrent devices that fell short of their initial promises (Gales et al., 2003; Fertl, 2009; Brandt et al., 2013). As with most things in life, the devil is always in the details and caveats, which can only be addressed by further research.

Given the potential value the new technology has to mitigate economic losses caused by depredation by marine mammals, the conclusions drawn by Götz \& Janik (2016) need validation by repeating the study in places that have higher densities of porpoise and seals than where their study was conducted. The caveats associated with their small resident population of just 15-30 seals, combined with the possibility that only 1 or 2 seals might have ultimately been the predatory culprits in their study needs addressing. It is equally important to replicate the study in places where motivation by seals, sea lions and toothed whales to feed may outweigh the effect that alarming sounds might have on their behaviours, and to repeat it in places where moving to alternative non-sonified fish farms may not be an option for the few individuals that specialize in depredation behaviour.

End-users and policy makers may naively believe that published studies are easily and directly applicable in the real life. However, the reality is that it is usually impossible to reproduce study methods as published (despite the best intentions of the researchers), which can lead to negative results or unintended consequences. For example, a method recommended by Yurk \& Trites (2000) to reduce predation by harbour seals Phoca vitulina richardsi on salmon smolts in a river using acoustic deterrence was subsequently installed by others, but reportedly failed to have any effect on seal predation (Puntledge River Hatchery personnel, pers. comm.), and resulted in all the seals in the river being shot. This type of experience highlights the need to treat applications of new technologies as scientific trials to be undertaken by scientists hand in hand with end-users to ensure that they are properly implemented, and that data are collected to monitor and evaluate whether the devices are truly effective and not causing greater harm.
The ultimate solution to protecting fish farms and fishing gear from marine mammals is not yet at hand, and there is unlikely to be a one-size-fits-all solution. Protecting fish raised in open-ocean meshed pens will likely prove to be a two-stepped process that begins with using physical barriers around pens to prevent predators from obtaining the fish (such as predator exclusion nets), and turning to sound (such as acoustic deterrence) as the second step to quickly push back any individuals that breach the protective perimeter. Some capture fisheries may be able to protect their catches using barriers (such as traps instead of hooks) or using smart fishing techniques (such as shorter soak times, or modified hauling techniques; e.g. Tixier et al., 2015), while others might find electrified nets and acoustic deterrence are effective in scaring predators in the short-term (Fertl, 2009).

Unfortunately, all technologically based deterrence methods are likely to fail in the long term as animals adapt to prolonged stimulus and find the rewards they receive to be greater than the price they pay to obtain them (Schakner \& Blumstein, 2013). New technologies often also equate to new problems and conflicts, it is just that no one knows yet what they are until the technology has been fully implemented. Thus, simple (but perhaps initially expensive) options that prevent predators from seeing or accessing the fish intended for human consumption are likely to be the most successful, while the technologically based solutions are likely to be most successful when used sparingly. Using one-two punch solutions that combine the two methods would seem to have the greatest likelihood of successfully reducing or removing conflicts between fisheries and marine mammals. They may also ultimately yield the peace of mind that society and those whose livelihoods depend on harvesting marine species seek to ensure that humans can co-exist with marine mammals with minimal conflict.

\section{References}

Brandt, M.J., Höschle, C., Diederichs, A., Betke, K., Matuschek, R., Witte, S. \& Nehls, G. (2013). Far-reaching effects of a seal scarer on harbour porpoises, Phocoena phocoena. Aquat. Conserv.: Mar. Freshwat. Ecosyst. 23, 222-232.

CERMAQ. (2012). Marine mammals and birds. Fact sheet - 2012.10.18. Available at: www.cermaq.com/wps/ wcm/connect/929239d5-c1b1-4137-9104-7fd136caa915/ FS_marine+mammals_2012.10.18.pdf?MOD=AJPERES

Fertl, D. (2009). Interference with fisheries. In Encyclopedia of marine mammals: 439-443. Perrin, W.F., Wursig, B. \& Thewissen, H.G.M. (Eds). San Diego: Academic Press.

Gales, N., Hindell, M. \& Kirkwood, R. (Eds). (2003). Marine mammals: fisheries, tourism and management issues. Collingwood: CSIRO Publishing.

Götz, T. \& Janik, V.M. (2011). Repeated elicitation of the acoustic startle reflex leads to sensitisation in subsequent 
avoidance behaviour and induces fear conditioning. BMC Neurosci. 12, 30.

Götz, T. \& Janik, V.M. (2015). Target-specific acoustic predator deterrence in the marine environment. Anim. Conserv. 18, 102-111.

Götz, T. \& Janik, V.M. (2016). Non-lethal management of carnivore predation: long-term tests with a startle reflexbased deterrence system on a fish farm. Anim. Conserv. 19, 212-221.

Howard, S.M.S., Lance, M.M., Jeffries, S.J. \& AcevedoGutiérrez, A. (2013). Fish consumption by harbor seals (Phoca vitulina) in the San Juan Islands, Washington. Fish. Bull. 111, 27-41.

Nash, C.E., Iwamoto, R.N. \& Mahnken, C.V. (2000). Aquaculture risk management and marine mammal interactions in the Pacific Northwest. Aquaculture 183, 307323.
Schakner, Z.A. \& Blumstein, D.T. (2013). Behavioral biology of marine mammal deterrents: a review and prospectus. Biol. Conserv. 167, 380-389.

Tixier, P., Garcia, J.V., Gasco, N., Duhamel, G. \& Guinet, C. (2015). Mitigating killer whale depredation on demersal longline fisheries by changing fishing practices. ICES J. Mar. Sci. 72, 1610-1620.

Tyndall, P. \& Cosgrove, R. (2016). Smart solutions to problems posed by seals to Irish fisheries. The Skipper. Available at: http://maramedia.ie/images/8-10Jan16.pdf Wilson, K., Lance, M., Jeffries, S. \& Acevedo-Gutiérrez, A. (2014). Fine-scale variability in harbor seal foraging behavior. PLoS ONE 9, e92838.

Yurk, H. \& Trites, A.W. (2000). Experimental attempts to reduce predation by harbour seals (Phoca vitulina) on outmigrating juvenile salmonids. Trans. Am. Fish. Soc. 129, 1243-1249. 